\title{
A novel 11 -hydroxysteroid dehydrogenase type1 inhibitor CNX-010-49 improves hyperglycemia, lipid profile and reduces body weight in diet induced obese C57B6/J mice with a potential to provide cardio protective benefits
}

Tharappel M Anil ${ }^{\dagger}$, Anilkumar Dandu ${ }^{\dagger}$, KrishnaReddy Harsha $^{\dagger}$, Jaideep Singh, Nitya Shree, Venkatesh Satish Kumar, Mudigere N Lakshmi, Venkategowda Sunil, Chandrashekaran Harish, Gundalmandikal V Balamurali, Baisani S Naveen Kumar, Aralakuppe S Gopala, Shivakumar Pratibha, ManojKumar Sadasivuni, Mammen O Anup, Yoganand Moolemath, Marikunte V Venkataranganna, Madanahalli R Jagannath ${ }^{*}$ and Baggavalli P Somesh

\begin{abstract}
Background: 11ß-hydroxysteroid dehydrogenase type1 (11ß-HSD1) converts inactive glucocorticoids to active glucocorticoids which, in excess, leads to development of the various risk factors of the metabolic syndrome. Recent studies clearly suggest that both increased expression and activity of $11 \beta-H S D 1$ in metabolically active tissues such as liver, muscle and adipose are implicated in tissue specific dysregulation which collectively contribute to the whole body pathology seen in metabolic syndrome. In the present study we have evaluated CNX-010-49, a highly potent, selective and 'pan tissue' acting 11ß-HSD1 inhibitor, for its potential to modulate multiple risk factors of the metabolic syndrome.
\end{abstract}

Methods: Male C57B6/J mice on high fat diet (DIO mice) were orally dosed with CNX-010-49 (30 mg/kg twice daily; $\mathrm{n}=8$ ) or vehicle for 10 weeks. Fasting glucose, triglycerides, glycerol, free fatty acids, body weight and feed intake were measured at selected time points. At the end of the treatment an OGT and subsequently organ histology was performed. In vitro, CNX-010-49 was evaluated in 3T3-L1 preadipocytes to assess impact on adipocytes differentiation, hypertrophy and lipolysis whereas in fully differentiated C2C12 cells and in primary mouse hepatocytes to assess the impact on glucose metabolism and hepatic glucose output respectively.

Results: CNX-010-49 a highly potent and selective pan tissue acting 11 $\beta$-HSD1 inhibitor $\left(\mathrm{EC}_{50}=6 \mathrm{nM}\right)$ significantly inhibits glucocorticoids and isoproterenol mediated lipolysis in mature 3T3-L1 adipocytes, improves muscle glucose oxidation, reduces proteolysis and enhances mitochondrial biogenesis. Also a significant inhibition of gluconeogenesis in primary mouse hepatocytes was observed. The treatment with CNX-010-49 resulted in a significant decrease in fasting glucose, improved insulin sensitivity and glucose tolerance. Treatment also resulted in a significant decrease in serum triglycerides levels and a complete inhibition of body weight gain without affecting feed consumption. A significant reduction in the serum biomarkers like Plasminogen activator inhibitor-1 (PAI-1), interleukin 6 (IL-6) and Fetuin-A with CNX-010-49 treatment was observed indicating a potential to modulate processes implicated in cardiovascular benefits.

(Continued on next page)

\footnotetext{
* Correspondence: m.r.jagannath@connexios.com

${ }^{\dagger}$ Equal contributors

Connexios Life Sciences Pvt Ltd, Bangalore, India
} 
Conclusions: These results indicate that inhibition of 11ß-HSD1 with CNX-010-49 can give a potential benefit in the management of metabolic dysregulations that are seen in type 2 diabetes.

Keywords: 11ß-HSD1, CNX-010-49, Glucose, Insulin sensitivity, Triglycerides, Adipogenesis and Body weight, Type 2 Diabetes, Cardiovascular risks

\section{Background}

Glucocorticoids (GCs) play a critical role in multiple metabolic processes, including glucose homeostasis, insulin sensitivity and lipid metabolism. Also it is well established that elevated glucocorticoid levels is linked with increased cardiovascular events [1]. Metabolic syndrome and Cushing's syndrome have some similar phenotypes that include hyperglycemia, visceral obesity, dyslipidemia and insulin resistance [2].

There are two isoforms of $11 \beta$-Hydroxysteroid dehydrogenase. $11 \beta$-HSD1 which converts the inactive $11 \beta$-keto form (cortisone in humans and 11-dehydrocorticosterone in rodents) to the active 11 $\beta$-hydroxylated GCs (cortisol in human and corticosterone in mice) [3]. It is expressed primarily in GC target tissues such as liver, skeletal muscle, adipose tissue and in the central nervous system where it amplifies local GC action [4]. 11ßHSD2 is highly expressed in classical aldosterone-selective target tissues, such as kidney [5] and prevents the inappropriate activation of mineralocorticoid receptors by cortisol. In conditions of excess NADPH, as seen in metabolic overload; $11 \beta$-HSD1 functions as a reductase and generates active cortisol while in situations of low levels of $\mathrm{NADPH}$ it functions as a dehydrogenase and generates inactive cortisone [6]. In humans, in vivo dehydrogenase activity of 11 $\beta$-HSD1 has been demonstrated [7].

Animals administered GCs show similar dysregulation in phenotype as seen in metabolic syndrome or T2DM where they observed increased fasting hyperglycemia, hyperinsulinemia and impaired $\beta$-cell response to oral glucose challenge. These animals have shown hepatic steatosis and increased ectopic lipid accumulation in muscle [8]. In adipocytes GCs increase lipolysis and hypertrophy in mature adipocytes [9] whereas in muscle GCs can increase proteolysis and insulin resistance. In another study, infusion of GCs has also shown in addition to the above observations hyperleptinemia, hypertriglyceridemia, significant decrease in uncoupling protein (UCP)-1 and UCP-3 expression [10]. The loss of UCP1 expression is shown to be attendant with decrease in non-shivering thermogenesis $[11,12]$.

In metabolic syndrome, the pathology is due to enhanced tissue level glucocorticoids [13]. Targeted disruption of the 11ß-HSD1 leads to improvement in glucose tolerance, improved lipid profile along with decreased gluconeogenic response [14]. Mice over expressing adipose
$11 \beta$-HSD1 develop visceral obesity which is further exacerbated by feeding high fat diet. These mice later developed all the phenotypes of metabolic syndrome including hypertension $[15,16]$.

$11 \beta$-HSD1 expression and activity are significantly increased in both skeletal muscle and fat tissue from obese type 2 diabetes (T2DM) patients and also in rodent models of disease suggesting a role for local glucocorticoids re-amplification in the development of obesity and the metabolic syndrome [13,17-20]. Also increased 11 $\beta$-HSD1 expression and activation in liver and adipose has demonstrated a clear link between its roles to T2DM as seen with glucose intolerance, increased insulin resistance, increased adiposity and body weight gain $[21,22]$. The concomitant increase in glucocorticoids in adipose leads to decreased adiponectin levels, increased TNF $\alpha$ and fasting glucose whereas hepatic overexpression increased insulinemia, LDL cholesterol and serum glucose levels. One study established the association impaired insulin signaling and 11 $\beta$-HSD1 expression/activity in skeletal muscle where dexamethasone treated myotubes showed reduced IRS1 expression, increased Ser307 phosphorylation of IRS1 and reduced downstream pSer473 Akt/PKB [23].

Pharmacological inhibition of $11 \beta$-HSD1 in different rodent models has demonstrated an improvement in glucose tolerance, insulin sensitivity as well as reduced body weight gain [24-30]. Also $11 \beta-H S D 1$ inhibition reduced serum triglycerides, cholesterol and frees fatty acids levels. Importantly, inhibition of $11 \beta-H S D 1$ reduces plaque progression and aortic cholesterol accumulation murine model of atherosclerosis.

To date a few small molecule inhibitors of $11 \beta-H S D 1$ have entered clinical studies. INCB13739 displayed statistically significant reductions in $\mathrm{HbA} 1 \mathrm{c}$ and glucose in T2DM patients where metformin monotherapy was inadequate [31]. MK-0916 decreased both blood pressure and body weight with a trend to reduce waist circumference and had no significant effect on blood glucose [32].

So far none of these interventions provided significant overall protection from metabolic syndrome. One can attribute this lack efficacy of $11 \beta-H S D 1$ inhibitors may be due to potential reversibility of the $11 \beta$-HSD1 enzymatic reaction. Selection of $11 \beta-H S D 1$ inhibitors which inhibit reductase activity than dehydrogenase activity and getting maximum inhibition in skeletal muscle apart 
from adipose and liver is very important. So there is still a need for intervention that alters $11 \beta-H S D 1$ enzyme activity and thereby provides a significant benefit in the management of metabolic syndrome.

Our understanding of $11 \beta$-HSD1 biology linking to metabolic syndrome suggests that inhibition of $11 \beta$-HSD1 with highly potent compound in all the metabolically active tissues like adipose, skeletal muscle and liver, will provide a complete benefit in controlling the disease. Also we screened and selected the compounds that have shown more inhibition of reductase activity than dehydrogenase activity along with good tissue distribution and inhibition in the above mentioned tissues. In this study, we have evaluated CNX-010-49 (MW = 408.5), a highly potent and selective 11ß-HSD1 inhibitor for its potential to control multiple facets of metabolic syndrome.

\section{Methods}

\section{Cell culture and treatment}

C2C12 cells (Mouse myoblasts, ATCC) were maintained in 24-well plates $\left(3 \times 10^{4}\right.$ cells/well) at $37^{\circ} \mathrm{C}$ in DMEM (Dulbecco's modified Eagle's medium) containing $25 \mathrm{mM}$ glucose and $10 \%$ FBS. When cells reached confluence, the media was supplemented with $25 \mathrm{mM}$ Glucose and 2\% FBS for myotubes formation. After 4 days of differentiation and myotubes formation, cells were treated with media containing GPCI ( $25 \mathrm{mM}$ glucose, $500 \mu \mathrm{M}$ palmitate, $500 \mathrm{nM}$ cortisone, $10 \mathrm{ng} / \mathrm{ml}$ of TNF $\alpha$, IL-1 $\beta$ \& IF $\gamma$ ) with or without $1 \mu \mathrm{M}$ of CNX-010-49 for $18 \mathrm{~h}$. Post $18 \mathrm{~h}$, cells were frozen in TRIZOL (Sigma, USA) for further analysis.

3T3-L1 cells (Mouse embryonic fibroblast, ATCC) were cultured in DMEM supplemented with $10 \%$ bovine calf serum and $25 \mathrm{mM}$ glucose. To induce the differentiation of 3T3-L1 preadipocytes, two days of post-confluence cells were treated with complete differentiated media (CDM) which contains $100 \mathrm{nM}$ insulin, $400 \mathrm{nM}$ cortisone or $1 \mu \mathrm{M}$ dexamethasone, $500 \mu \mathrm{M}$ IBMX (isobutylmethylxanthine) with or without $1 \mu \mathrm{M}$ of CNX-010-49. Media was changed for every 2 days with fresh media containing $100 \mathrm{nM}$ insulin and CNX-010-49 till day 6. On day 7 cells were cultured in regular culture media and after $24 \mathrm{~h}$, triglyceride content of the cells were estimated (Diagnostic systems, Germany). One set of cells were processed for Oil red $\mathrm{O}$ staining. Treated cells were washed twice with phosphate-buffered saline (PBS), fixed in $10 \%$ formalin for $1 \mathrm{~h}$ and washed once with $60 \%$ isopropanol. Cells were then stained with $60 \%$ of filtered oil red $\mathrm{O}$ stock solution ( $0.35 \mathrm{~g}$ of oil red O (Sigma, USA) in $100 \mathrm{ml}$ of $100 \%$ isopropanol) for $15 \mathrm{~min}$. Cells were washed thrice with water for $5 \mathrm{~min}$ each and later visualized under microscope.

For the measurement of adipocytes hypertrophy, mature adipocytes were treated with media containing GPCI (25 mM glucose, $500 \mu \mathrm{M}$ palmitate, $500 \mathrm{nM}$ cortisone,
$10 \mathrm{ng} / \mathrm{ml}$ of TNF $\alpha$, IL- $1 \beta$ \& IF $\gamma$ ) with or without $1 \mu \mathrm{M}$ of CNX-010-49 for 48 h. Post 48 h, cells were lysed and triglyceride content of the cells was estimated (Diagnostics system, Germany).

For lipolysis assay, fully differentiated 3T3-L1 cells (mature adipocytes) were treated with $1 \mu \mathrm{M}$ of isoproterenol and $100 \mathrm{nM}$ cortisone with or without $1 \mu \mathrm{M}$ CNX-010-49 for $18 \mathrm{~h}$. Glycerol released in the medium was assayed using Free Glycerol Reagent (Sigma, USA). Lipolysis data was normalized to total protein.

\section{Isolation, culturing and hepatic glucose release in primary hepatocytes}

Hepatocytes from Swiss albino mice were prepared as per the method of Seglen [33]. Hepatocytes were collected by centrifugation at $300 \mathrm{rpm}$ for $3 \mathrm{~min}$ at $4^{\circ} \mathrm{C}$. The viability of the hepatocytes was measured by Trypan blue exclusion and then seeded onto collagen coated 6 well/96-well tissue culture plates in DMEM containing $20 \%$ FBS and $10 \mathrm{mM}$ Nicotinamide and maintained at $37^{\circ} \mathrm{C}$ in a humidified atmosphere of $5 \% \mathrm{CO}_{2}$. After $3 \mathrm{~h}$ of attachment, the medium was replaced with fresh growth medium.

To measure glucose release from the hepatocytes, cells were treated with gluconeogenesis inducing media (glucose free DMEM media with $5 \mathrm{mM}$ lactate, $5 \mathrm{mM}$ pyruvate, $1 \mu \mathrm{M}$ cortisone, $10 \mu \mathrm{M}$ forskolin, $1 \% \mathrm{FBS}$ with or without $1 \mu \mathrm{M}$ of CNX-010-49) for $18 \mathrm{~h}$. Glucose released in the media was measured using GOD method (Diagnostic systems, Germany). Values were normalized to total protein. Also one set of treatment was processed for gene expression analysis.

\section{$11 \beta$-HSD 1 cell-based enzymatic activity assay}

CHO-K1 (ATCC) cells stably expressing human $11 \beta$ HSD1 gene (OriGene Technologies, USA) and fully differentiated subcutaneous human adipocytes (Zen-Bio, Inc, USA) were used for determination of half-maximum inhibitory concentration $\left(\mathrm{IC}_{50}\right)$ of $\mathrm{CNX}-010-49$ towards human 11ß-HSD1 isoform. Fully differentiated C2C12 cells (expressing native $11 \beta$-HSD1 protein) were used to determine $\mathrm{IC}_{50}$ towards the mouse isoform.

For determination of $\mathrm{IC}_{50}, \mathrm{CHO}-\mathrm{K} 1$ cells were seeded in a serum free Ham's F-12 media containing $400 \mathrm{nM}$ cortisone and $500 \mu \mathrm{M}$ NADPH with or without CNX-010-49. Inhibitor was dissolved in DMSO and diluted in media serially to get different concentration to determine $\mathrm{IC}_{50}$ (8 concentrations were used starting from $0.001 \mathrm{nM}$ to $3 \mu \mathrm{M})$. Post $18 \mathrm{~h}$ treatment, the culture media was analyzed for the inhibition of cortisone to cortisol conversion using LCMS/MS (ABI-4000 QTRAP). Similar protocol was followed with $\mathrm{C} 2 \mathrm{C} 12$ cells to determine $\mathrm{IC}_{50}$ (from 1 $\mathrm{nM}$ to $3 \mu \mathrm{M}$ ) for mouse isoform. 


\section{HSD-related enzymes cell-based activity assay}

CHO-K1 cells transiently expressing human 11 $\beta-H S D 2$ and $17 \beta-$ HSD3 gene (OriGene Technologies, USA) and T47D (ATCC) breast cancer cell line that expresses $17 \beta$ HSD1 were used to determine inhibitory constants towards the respective enzymes.

For determination of inhibition towards HSD-related enzymes; cortisol was used as substrate for 11 $\beta$-HSD2 (which will be converted to cortisone), androstenedione for $17 \beta$-HSD3 (converted to testosterone) and estrone for $17 \beta$-HSD1 (converted to estradiol). Post $18 \mathrm{~h}$ of treatment, the culture media was analyzed and inhibition of respective substrate conversion was analyzed using LCMS/MS (ABI-4000 QTRAP).

$11 \beta-H S D 1$ reductase and dehydrogenase enzymatic assay $\mathrm{N}$-terminal deleted human $11 \beta$-HSD1 pure protein (cloned, expressed using pET27b vector in bacteria and later purified in-house using Ni-NTA agarose beads) was used to evaluate both reductase and dehydrogenase enzymatic activity. For reductase activity, the reaction buffer contained $200 \mathrm{nM}$ cortisone and $500 \mu \mathrm{M}$ NADPH. For dehydrogenase activity, the reaction buffer contain $200 \mathrm{nM}$ cortisol and $500 \mu \mathrm{M}$ NADP. After $4 \mathrm{~h}$ incubation at $37^{\circ} \mathrm{C}$, converted cortisol or cortisone was analyzed using LCMS/MS (ABI-4000 QTRAP).

\section{In vivo efficacy studies in C57BL/6j mice on high fat diet}

Six week old male C57BL/6 J mice were housed 2 per polypropylene cage, maintained at $23 \pm 1^{\circ} \mathrm{C}, 60 \pm 10 \%$ humidity, exposed to $12 \mathrm{~h}$ cycles of light and dark. Control group ( $\mathrm{n}=8)$ animals were fed a standard chow diet (D10001; 10\% kcal from fat); HFD (high fat diet) group $(\mathrm{n}=16)$ fed high fat diet (D12492; 60\% kcal from Research Diets, Inc., New Jersey, USA). After 11 weeks of diet intervention, the HFD fed animals were randomized to either vehicle (HFD control) or CNX-01-49 (30 mg/kg, orally twice a day in $0.5 \%$ Carboxy methyl cellulose) treatment groups $(\mathrm{n}=8)$ based upon body weight, glucose AUC during OGTT and fasting blood glucose. The treatment was further continued for another 10 weeks. Body weight, glucose in fasting $(6 \mathrm{~h})$ and fed state, triglycerides in fasting (12 h) state were measured weekly and plasma insulin was measured at the end of study. At the end of the study, blood was collected for determination of plasma glycerol and leptin levels following which the mice were euthanized under isoflurane anaesthesia and necropsied. Adipose tissues were weighed and a portion was immediately collected in formalin and processed for histological examination. Animal experiment protocols and experimental procedures were approved by the Connexios Institutional Animal Ethics Committee which is in accordance with the ARRIVE guidelines (Additional file 1) [34].

\section{Quantitative PCR analysis}

At the end of treatment periods, total RNA was extracted from different tissues using TRIZOL. Equal amount of RNA was reverse transcribed and later amplified using specific primers. Beta-actin was used as an internal control for the quantitative analysis. The primer sequence is available upon request.

\section{DNA isolation and quantitative real-time PCR assay for mitochondrial copy number}

DNA from C2C12 myotubes was isolated using Phenol extraction method. Quantitative real-time PCR was performed for mtND1 (mitochondrial gene) using DNA as template and normalized to HPRT (nuclear gene) gene.

\section{Blood and plasma assay}

Blood glucose was measured using hand-held Accucheck glucometer (Roche Diagnostics, Germany). An ultra-sensitive insulin enzyme-linked immunosorbent assay (ELISA) kit (Downers Grove, USA) was used to determine plasma insulin levels. Circulating serum TG, plasma glycerol and leptin were estimated using the TG estimation kit (Diagnostic systems, Germany), glycerol estimation kit (Sigma, USA) and Leptin estimation kit ( $\mathrm{R} \& \mathrm{D}$ systems, USA) respectively as per the manufacturer's instruction.

\section{Ex vivo $11 \beta-H S D 1$ inhibition assay}

The duration and percent inhibition of $11 \beta$-HSD1 activity by CNX-010-49 (30 mg/kg, single dose orally) in different tissues (liver, adipose, skeletal muscle and brain) in Swiss albino mice was evaluated by an ex vivo $11 \beta$-HSD1 inhibition assay. We have used 4 animals for every time point in the study. After dosing the animals orally, animals were sacrificed at each time point and different tissues (liver, skeletal muscle, adipose and brain) were removed, minced and incubated with cortisone for $16 \mathrm{~h}$. Converted cortisol was measured by LCMS/MS (ABI-4000 QTRAP) and the percent inhibition of $11 \beta$-HSD1 activity relative to vehicle-treated controls was calculated.

\section{Oral Glucose Tolerance Test (OGTT)}

After a 6 h fast, CNX-010-49 or vehicle was administered $60 \mathrm{~min}$ prior to administration of glucose $(2 \mathrm{~g} / \mathrm{kg}$ body $\mathrm{wt})$ by oral gavage. Blood samples were collected from the tail vein 60 min before treatment and at $0,10,20,30,60,90$ and $120 \mathrm{~min}$ after glucose load for estimating glucose.

\section{Insulin tolerance test (ITT)}

ITT was performed in $6 \mathrm{~h}$ fasted mice during 9th week of treatment. Blood samples were collected prior to and at $0,15,30$ and $60 \mathrm{~min}$ after insulin (human R Insulin, Eli Lilly) administration (2 IU/kg, i.p.) for glucose estimation. 


\section{Pyruvate tolerance test (PTT)}

Pyruvate Tolerance Test (PTT) was performed in overnight fasted mice during 10th week of treatment. Blood samples were collected from the tail vein $60 \mathrm{~min}$ before treatment and at $0,15,30,60,90$ and $120 \mathrm{~min}$ after pyruvate load ( $2 \mathrm{~g} / \mathrm{kg}$, intraperitonial) for estimating glucose. The data was analyzed for change in glucose levels in CNX-010-49 treated animals when compared with HFD control.

\section{Measurement of thermogenesis}

For the cold exposure experiment, mice were housed individually and transferred to a cold environment with an ambient temperature of $4^{\circ} \mathrm{C}$. Body temperature was assessed at the end of treatment period using a rectal probe. Temperature was measured for every $15 \mathrm{~min}$ for 60-75 min and animals were then brought to room temperature.

\section{Estimation of liver TG}

Liver TG was extracted according to Folch's method. The TG from liver homogenate was extracted with chloroform: methanol (2:1) mixture, the organic layer dried in a speed vac, re-suspended in isopropyl alcohol and liver TG content was analyzed by using TG estimation kit (Diagnostic systems, Germany).

\section{Adipose tissue collection, immunofluorescence and image analysis}

Subcutaneous adipose tissue was removed and was fixed in $10 \%$ buffered neutral formalin. It was then embedded in paraffin, sectioned and stained. All adipose sections were viewed at 40X magnification, and images were captured using Zeiss microscope connected via camera to a computer (progres ${ }^{\bullet}$ capture pro 2.1 camera). Adipocytes size measurement was performed using a computerassisted image analysis progres ${ }^{\oplus}$ capture pro software. From each animal 10 images were measured. The area of each adipocyte was measured by tracing the cell boundary on the images captured. All adipocytes that had complete cell boundary were measured. Data obtained after measurement were averaged to individual animal and later group mean and SEM were calculated.

For PRDM16 and UCP1 immuno staining, subcutaneous adipose sections were de-paraffinized and blocked in $1 \% \mathrm{BSA}$ in PBS for $30 \mathrm{~min}$ at RT and incubated with PRDM16 (ProSci, USA) or UCP1(Abcam, USA) primary antibodies for $90 \mathrm{~min}$ at RT, followed by washing with PBS. Sections were then incubated with secondary antibody (goat anti-rabbit Alexa Fluor 555 secondary antibody, Molecular Probes, Invitrogen) for $30 \mathrm{~min}$ at RT and mounted using fluromount. Localization of PRDM16 and UCP1 were assessed and the images were captured at 40X magnification.

\section{Assessment of JNK and elF2a phosphorylation}

At the end of treatment period, $10 \mathrm{mg}$ of muscle (soleus) and subcutaneous adipose tissues were collected from each animal in respective groups. Lysates were prepared by homogenization and $50 \mu \mathrm{g}$ lysate from each group was subjected to SDS-PAGE, transferred onto nitrocellulose membranes and probed with antibodies against phospho-JNK, phospho-eIF2 $\alpha$, total JNK and Actin (Cell signaling, USA) and developed by enhanced chemiluminescence (West Pico, Thermo Scientific, USA).

\section{Estimation of serum biomarkers}

Serum was collected at the end of the study and ELISA (Enzyme Linked Immunosorbent Assay) was performed as per the kit protocol to measure changes in leptin (R\&D system), PAI-1 (Invitrogen), Fetuin-A (Uscn Life Science Inc) and IL-6 (R\&D systems) levels in the serum.

\section{Statistical analysis}

Prism 5.01 software (GraphPad Software, San Diego CA) was used for statistical analysis. All the values are expressed as Mean \pm SEM and ' $n$ ' indicates the number of animals in each group. When only two groups were analyzed, statistical comparison was conducted by Oneway ANOVA followed by Dunnett's test. Repeated measure based parameters (such as weekly fasting glucose, serum triglycerides and body weight) were analyzed using two-way ANOVA for repeated measures followed by Bonferroni correction (with time and diet/inhibitor treatment as factors). Statistical details (p-value, F, and degree of freedom (Df)) are provided in the figure legends along with the results of the two-way ANOVA testing. $\mathrm{P}<0.05$ was considered statistically significant.

\section{Results}

CNX-010-49 is a highly potent, selective inhibitor and has a good pharmacodynamic activity

CNX-010-49 is a highly potent $11 \beta$-HSD1 inhibitor towards both human and mouse isoforms with an $\mathrm{IC}_{50}$ of $6 \mathrm{nM}$ and $64 \mathrm{nM}$ respectively (Figure $1 \mathrm{~A} \mathrm{\&} \mathrm{B)} \mathrm{as} \mathrm{estab-}$ lished from cells over expressing human 11 $\beta$-HSD1 in $\mathrm{CHO}-\mathrm{K} 1$ cell and fully differentiated mouse $\mathrm{C} 2 \mathrm{C} 12$ myotubes respectively. $\mathrm{IC}_{50}$ for $\mathrm{CNX}-010-49$ in primary human mature adipocytes is $13 \mathrm{nM}$ (Figure 1C). CNX010-49 inhibits reductase activity more than dehydrogenase activity (>100X, Figure 1D). CNX-010-49 is highly selective inhibitor with no inhibition up to $100 \mu \mathrm{M}$ towards $11 \beta$-HSD2, $17 \beta$-HSD1 and 17 $\beta$-HSD3 (Figure 1E, F \& G). In a single dose pharmacodynamic activity evaluation in Swiss albino mice, oral administration of CNX-010-49 at $30 \mathrm{mg} / \mathrm{kg}$ inhibited $11 \beta$-HSD1 activity by $58 \%$ and $24 \%$ at $1 \mathrm{~h}$ and $7 \mathrm{~h}$ respectively in liver. In adipose, the inhibition was $41 \%$ at $1 \mathrm{~h}$ and continued to be same till $7 \mathrm{~h}$. In 

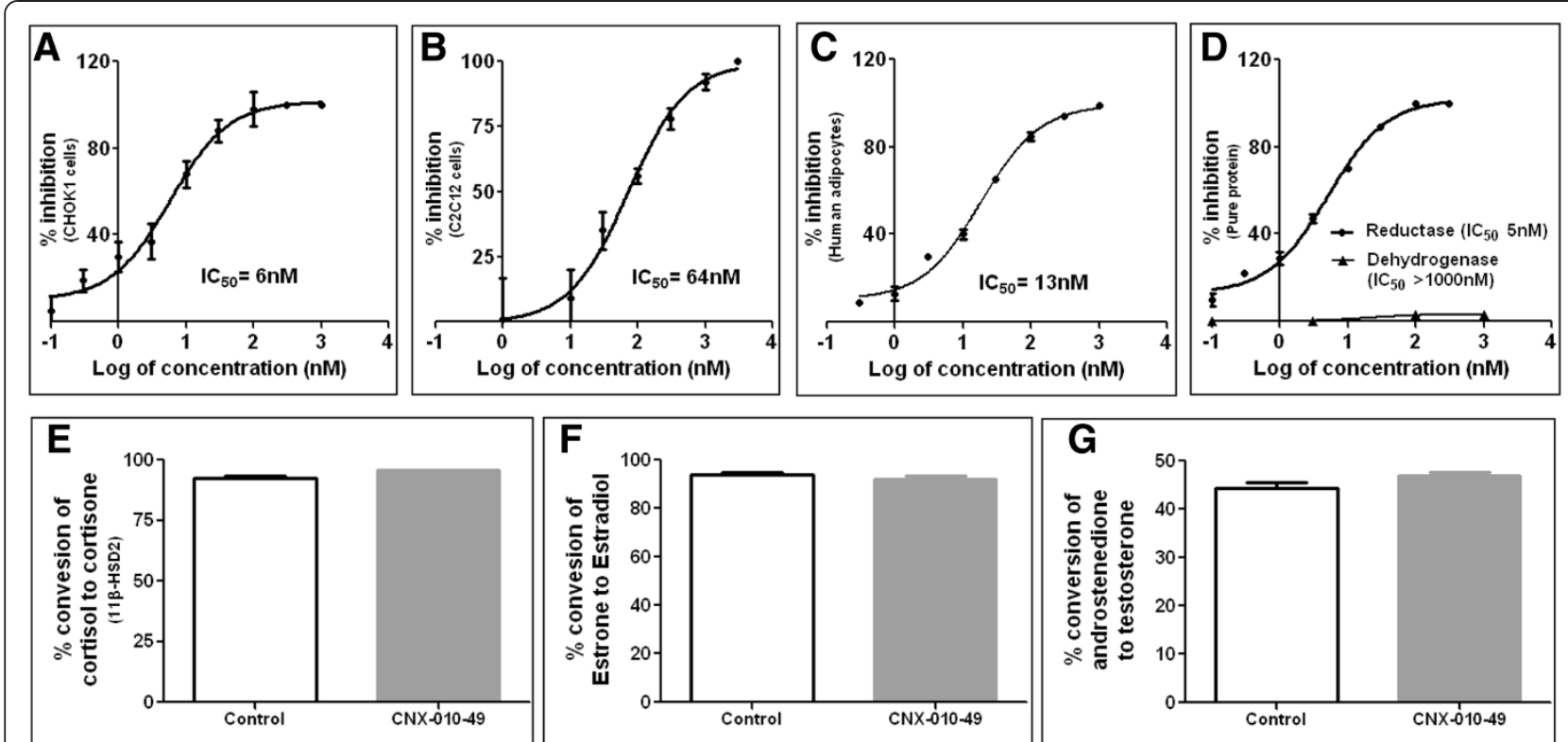

Figure 1 Potency and selectivity of CNX-010-49. Inhibition curve with increasing concentrations of CNX-010-49 for reductase activity in CHOK1 cells stably expressing human $11 \beta-H S D 1$ (A), Mouse C2C12 cells (B), fully differentiated human adipocytes (C), both reductase and dehydrogenase activity with recombinant human $11 \beta-H S D 1$ protein (D) as mentioned in the materials and methods. Selectivity of CNX-010-49 (100 $\mu$ M) against HSD related enzymes were evaluated in CHOK1 cells transiently over expressing human 11ßHSD2 and 17ß HSD3 respectively (E \& G) and T47D cells for 17ßHSD1 (F). Data are means of three individual experiments with standard deviations $(n=6)$.

skeletal muscle, the inhibition was $\sim 38 \%$ at $1 \mathrm{~h}$ and $7 \mathrm{~h}$. At end of $24 \mathrm{~h}$, there was no inhibition of $11 \beta$-HSD1 observed (data not shown). However there was no inhibition observed in brain (Table 1).

CNX-010-49 decreases liver gluconeogenic activity in primary cultures of mouse hepatocytes and hence has a potential to control fasting glucose

In the presence of gluconeogenic substrates (lactate and pyruvate) along with signaling molecules (forskolin and glucocorticoids), mouse hepatocytes showed a significant increase in hepatic glucose release along with increase in mRNA expression of both G6PC (glucose-6-phosphatase, catalytic subunit) and PEPCK (phosphoenolpyruvate carboxykinase) (5 and 9 fold increase respectively against control cells) which are the key mediators of hepatic glucose production. Inhibition of $11 \beta-\mathrm{HSD} 1$ by $1 \mu \mathrm{M}$ of CNX-010-49 significantly reduced hepatic glucose release by $\sim 45 \%$ and mRNA expression of both G6PC and
PEPCK (40\% and 70\% respectively) indicating a potential of CNX-010-49 to reduce fasting glucose (Figure 2A-C).

CNX-010-49 increases muscle glucose oxidation, reduces muscle proteolysis and increases mitochondrial biogenesis In $\mathrm{C} 2 \mathrm{C} 12$ myotubes, the presence of excess free fatty acids, inflammatory cytokines and cortisone (in vitro disease mimicking condition); PDK4 (pyruvate dehydrogenase kinase 4) mRNA expression was increased by more than 4 fold as compared to vehicle control. Inhibition of $11 \beta$-HSD1 by CNX-010-49 reduced PDK4 expression by $40 \%$ (Figure 3A). Under the similar condition, we observed around 2 fold increase in mRNA expression of TRIM63 (tripartite motif containing 63; an E3 ubiquitinprotein ligase which is known to enhance muscle proteolysis) as compared to vehicle control. Treatment with CNX-010-49 reduced the expression by $30 \%$ (Figure 3B). Mitochondrial copy number was decreased by $\sim 75 \%$ under disease mimicking condition compared to vehicle

Table 1 Effect of CNX-010-49 on pharmacodynamic activity

\begin{tabular}{|c|c|c|c|c|c|c|c|c|}
\hline \multirow[b]{2}{*}{ Time (h) } & \multicolumn{2}{|c|}{ Liver } & \multicolumn{2}{|c|}{ Skeletal muscle } & \multicolumn{2}{|c|}{ Adipose } & \multicolumn{2}{|c|}{ Brain } \\
\hline & 1 & 7 & 1 & 7 & 1 & 7 & 1 & 7 \\
\hline \% inhibition with CNX-010-49 & $58 \pm 2$ & $24 \pm 6$ & $41 \pm 4$ & $44 \pm 5$ & $38 \pm 7$ & $42 \pm 5$ & 0 & 0 \\
\hline
\end{tabular}

After oral administration of CNX-010-49 at $30 \mathrm{mg} / \mathrm{kg}$ (single dose) to Swiss albino mice ( $\mathrm{n}=4$ per time point), pharmacodynamic activity of CNX-010-49 at different time points was measured in liver, muscle, adipose and brain tissues ex vivo as described in Methods. 

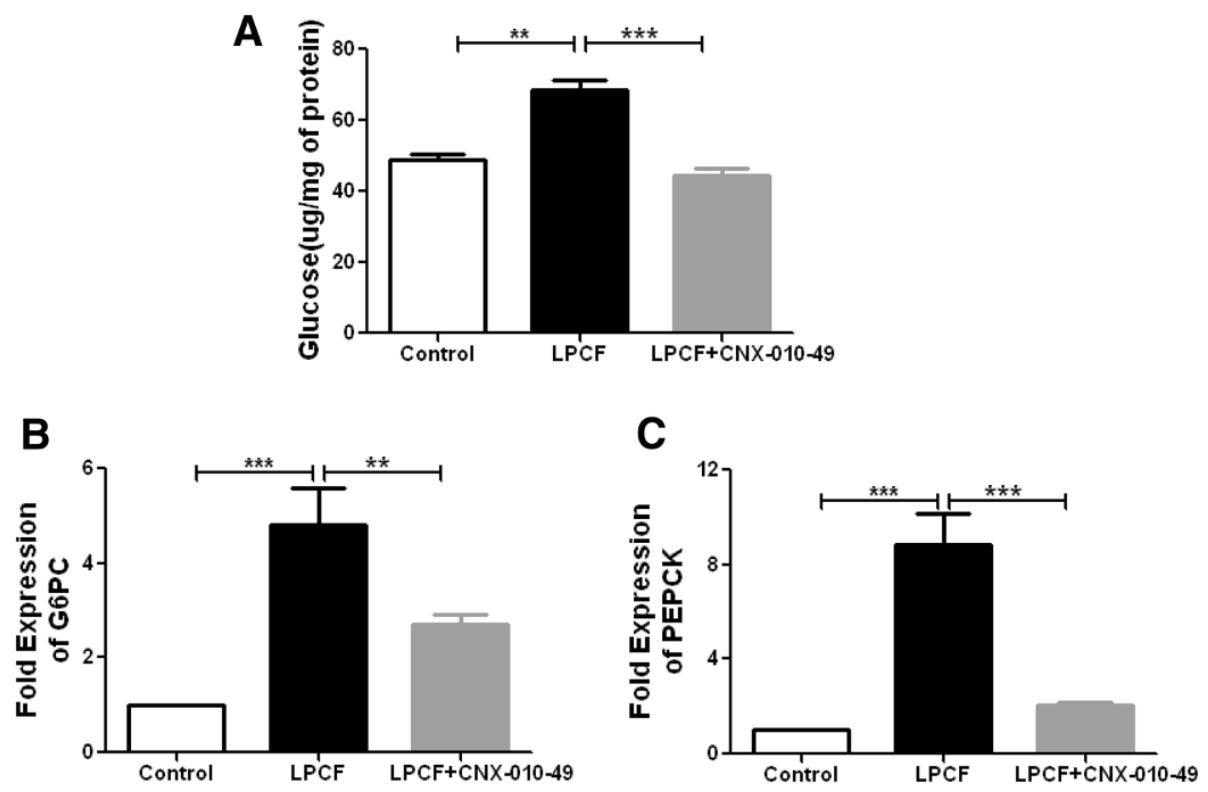

Figure 2 Effect of CNX-010-49 on liver gluconeogenesis in primary mouse hepatocytes. Mouse primary hepatocytes were treated with glucose free media containing LPCF ( 5 mM Lactate, 5 mM Pyruvate, $1 \mu \mathrm{M}$ cortisone, $10 \mu \mathrm{M}$ of forskolin) with or without $1 \mu \mathrm{M}$ of CNX-010-49 for $18 \mathrm{~h}$. Post $18 \mathrm{~h}$, glucose released in the media (A) and mRNA expression gluconeogenic markers G6PC and PEPCK (B \& C) were measured as mentioned in Methods. All the values are expressed as Mean \pm SEM. Statistical comparison was conducted by One-way ANOVA followed by Dunnett's test $(n=6)\left({ }^{*} P<0.05,{ }^{* *} P<0.01\right.$ and $\left.{ }^{* * *} P<0.001\right)$.
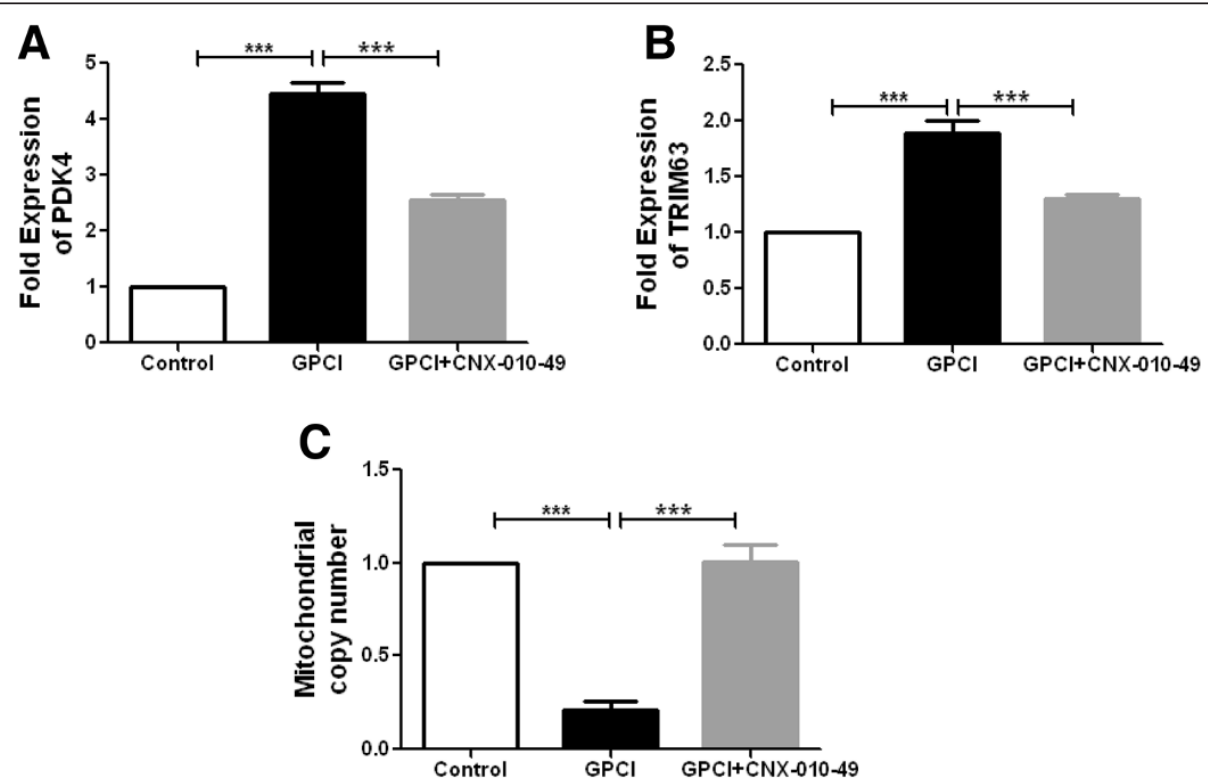

Figure 3 Effect of CNX-010-49 on muscle glucose oxidation, proteolysis and mitochondrial biogenesis. C2C12 myotubes were treated with GPCI (25 mM Glucose, $500 \mu \mathrm{M}$ Palmitate, $1 \mu \mathrm{M}$ of Cortisone, $10 \mathrm{ng} / \mathrm{ml}$ of each inflammatory cytokines (TNFa, IL1 $\beta$ and IFN )) for $18 \mathrm{~h}$ with or without $1 \mu \mathrm{M}$ of CNX-010-49. Post $18 \mathrm{~h}$, mRNA expression of PDK4 and TRIM63 (A \& B) and mitochondrial gene ND1 (C) were measured as mentioned in Methods. All the values are expressed as Mean \pm SEM. Statistical comparison was conducted by One-way ANOVA followed by Dunnett's test $(n=6)\left({ }^{*} P<0.05,{ }^{* *} P<0.01\right.$ and $\left.{ }^{* *} P<0.001\right)$. 
control. Inhibition of $11 \beta-H S D 1$ by CNX-010-49 restored the mitochondrial number (Figure 3C).

\section{CNX-010-49 inhibits both adipocytes differentiation, lipolysis and hypertrophy}

Conversion of inactive cortisone to active cortisol by $11 \beta$-HSD1 favors adipogenesis. CNX-010-49 treatment reduced the differentiation/adipogenesis capacity by $34 \%$ as measured by accumulation of triglycerides in adipocytes as well as by oil red $\mathrm{O}$ staining (Figure 4A \& B). Both cortisone and isoproterenol stimulated lipolysis by 2 fold in mature 3T3-L1 adipocytes as measured by the release of glycerol in the culture medium. CNX-010-49 treatment reduced adipocytes lipolysis by $25 \%$ (Figure $4 \mathrm{C}$ ). Excess metabolic overload and inflammation mediated hypertrophy of adipocytes as measured by enhanced triglyceride accumulation, was reduced by $35 \%$ with CNX010-49 treatment (Figure 4D).

\section{CNX-010-49 reduces fasting blood glucose in DIO mice}

Compared to the lean control animals the HFD control animals exhibited a significant increase in fasting glucose (136 \pm 6 vs. $200 \pm 8 \mathrm{mg} / \mathrm{dl} ; \mathrm{P}<0.001)$ during the entire study period, indicating development of insulin resistance and hyperglycemia (Figure 5A). In CNX-010-49 treated animals, fasting glucose started decreasing from week 5 of treatment and by the end of treatment period reached a significant $15 \%$ reduction $(170 \pm 6$ vs $200 \pm 5 \mathrm{mg} / \mathrm{dl} ; \mathrm{P}<$ $0.01)$ when compared with the HFD control mice.

We evaluated the gluconeogenic state of liver before terminations of the study by performing a pyruvate tolerance test where animals were challenged with gluconeogenic substrate pyruvate and glucose levels in serum was measured. Compared to lean control animals, HFD animals showed an increase in serum glucose AUC (20736 \pm 1013 vs $26511 \pm 2057)$ upon pyruvate challenge. When compared with HFD control animals, CNX-01-49 treatment resulted in significant decrease in glucose AUC (26511 \pm 2057 vs $22775 \pm 97)$ amounting to a $~ 15 \%$ suggesting decreased gluconeogenesis (Figure 5B).

The HFD control animals showed an $~ 25 \%$ and $~ 50 \%$ increase in fasting glycerol and free fatty acid levels respectively when compared to lean control animals. CNX010-49 treated animals showed $\sim 18 \%$ and $20 \%(\mathrm{P}<0.05)$ decrease in fasting glycerol and free fatty acids respectively (Figure 5C \& D). This indicates that treatment with CNX010-49 modulates adipocytes physiology and reduces supply of pro-gluconeogenic substrates to the liver.

\section{CNX-010-49 improves glucose tolerance in DIO mice}

To examine whether glucose intolerance in HFD mice was improved by the CNX-010-49 treatment, an oral
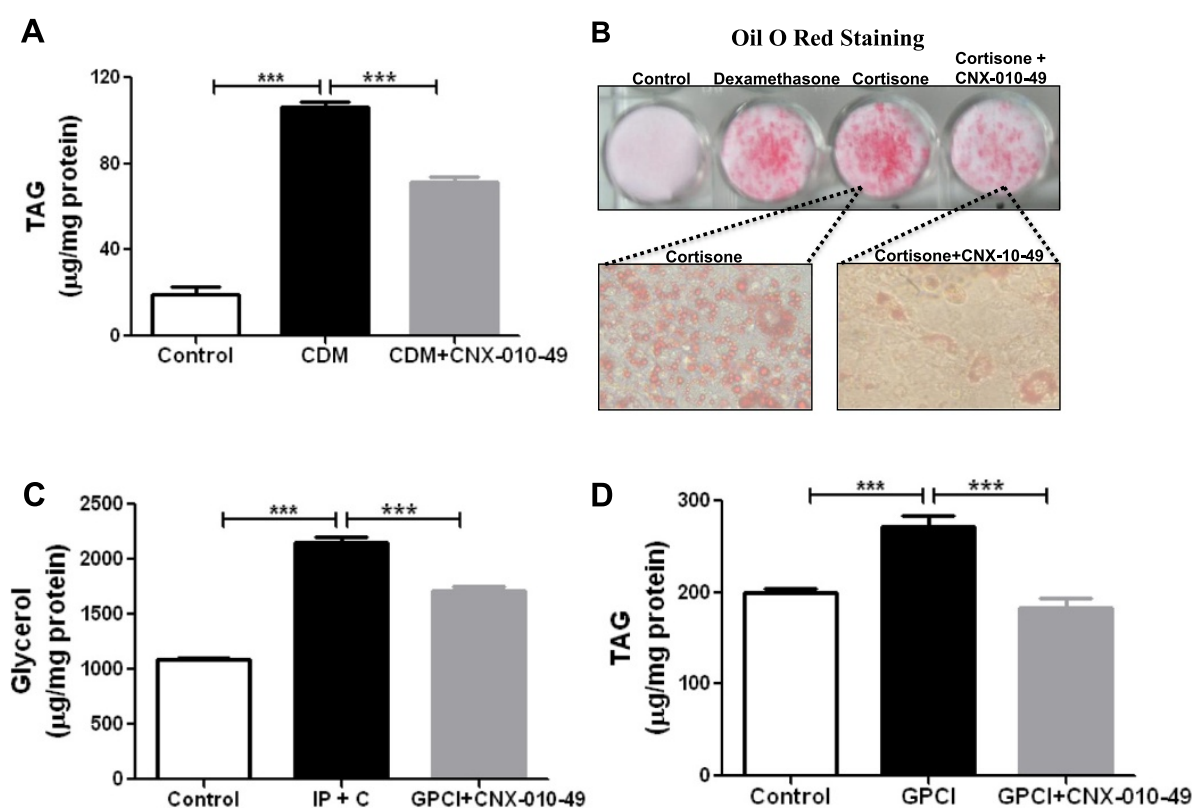

Figure 4 Effect of CNX-010-49 on adipocytes differentiation, hypertrophy and lipolysis. Mouse 3T3-L1 preadipocytes were differentiated into mature adipocytes using complete differentiating media (CDM) in the presence and absence of $1 \mu \mathrm{M}$ of CNX-010-49. The extent of inhibition of adipocytes differentiation was assessed by measuring triglyceride levels (A) and Oil red O staining (B). For inhibition of lipolysis, mature adipocytes were treated with $1 \mu \mathrm{M}$ isoproterenol and $100 \mathrm{nM}$ cortisone with or without $1 \mu \mathrm{M}$ of CNX-010-49 for $18 \mathrm{~h}$. Post $18 \mathrm{~h}$, glycerol released into the media was measured (C). For inhibition of adipose hypertrophy, mature adipocytes were treated with GPCl $(25 \mathrm{mM}$ glucose, $500 \mu \mathrm{M}$ palmitate, $1 \mu \mathrm{M}$ cortisone, $10 \mathrm{ng} / \mathrm{ml}$ of inflammatory cytokines (TNFa, IL1 $\beta$, IFN )) for $48 \mathrm{~h}$ with or without $1 \mu \mathrm{M}$ of CNX-010-49. Post 48 h, triglyceride accumulation was measured (D). All the values are expressed as Mean \pm SEM. Statistical comparison was conducted by One-way ANOVA followed by Dunnett's test $(n=6)\left({ }^{*} P<0.05,{ }^{* *} P<0.01\right.$ and $\left.{ }^{* * *} P<0.001\right)$. 

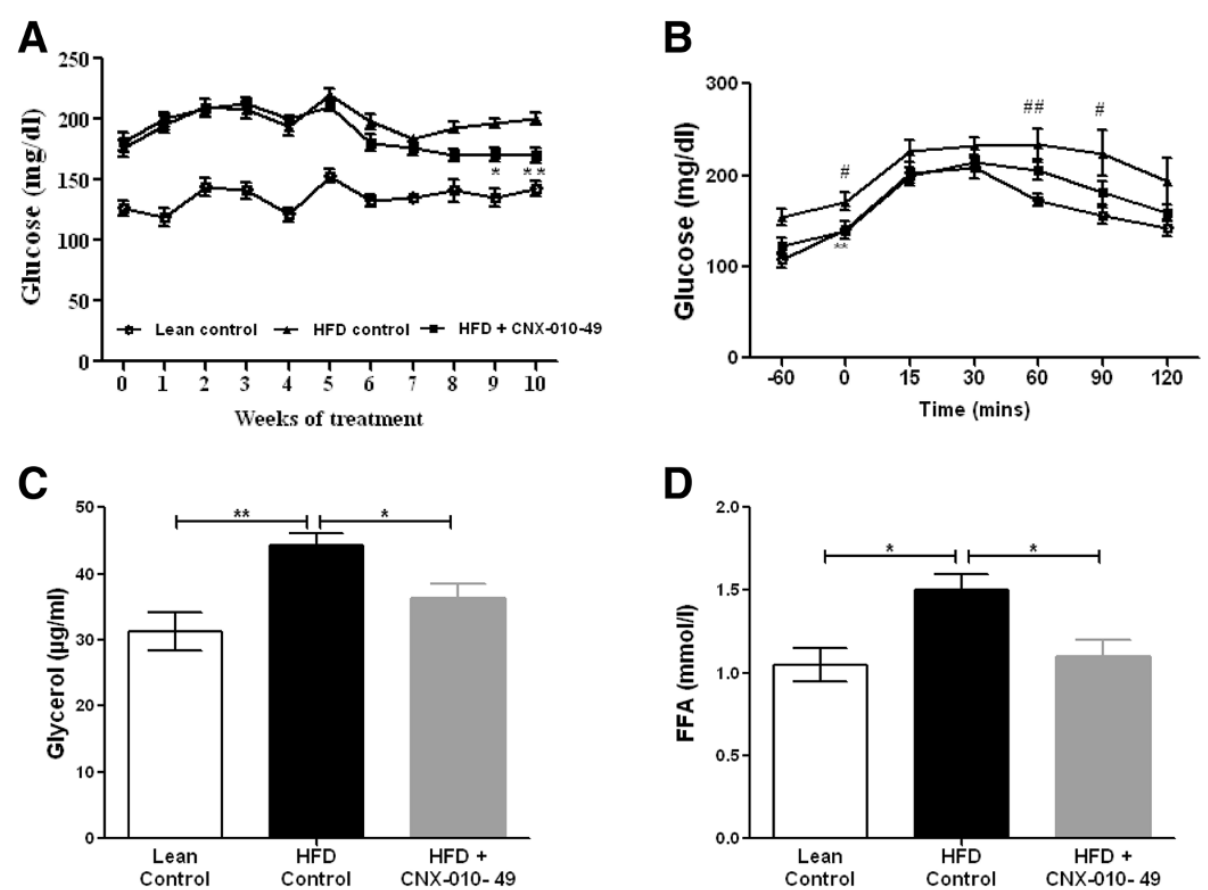

Figure 5 Effect of CNX-010-49 on fasting glucose in DIO mice of HFD. Fasting Glucose levels (A) were monitored weekly. To measure the gluconeogenic state of liver, pyruvate tolerance test (B) was performed as described in the Methods. At the end of the treatment period, serum glycerol (C) and free fatty acids (D) were measured as described in the Methods. Data in all panels are mean \pm SEM $(n=8$ mice/group). Statistical comparison was conducted by One-way ANOVA followed by Dunnett's test or repeated measures ANOVA followed by Bonferroni correction (A \& B) ( $n=8$ mice/group). Two-way repeated measures ANOVA indicated that CNX-010-49 significantly reduced the fasting glucose $(p=0.01 ; F=5.08 ;$ $\mathrm{Df}=22)\left(\#\right.$ - significance of HFD control against lean control, ${ }^{*}$ - significance of CNX-010-49 treatment against HFD control) $\left({ }^{*} \mathrm{P}<0.05\right.$, ${ }^{* *} \mathrm{P}<0.01$ and ${ }^{* *} P<0.001$ ).

glucose tolerance test was performed at the end of the treatment. Upon oral glucose challenge, a significant increase in the glucose excursion in HFD mice were observed when compared to lean control (AUC of $57376 \pm$ 1382 in HFD control vs $33803 \pm 1919$ in lean control; $\mathrm{P}<$ 0.001). However CNX-010-49 treatment showed $~ 13 \%$ decrease in glucose levels $(49680 \pm 734$ in treatment vs $57376 \pm 1382$ in HFD control; $\mathrm{P}<0.05)$ indicating the potential of CNX-010-49 to reduce post prandial hyperglycemia (Figure 6B).

\section{CNX-010-49 reduces hyper insulinemia and improves peripheral insulin sensitivity}

In comparison with the lean control animals, HFD control animals showed significant increase in fasting insulin levels $(0.59 \pm 0.07$ vs $1.94 \pm 0.29 \mathrm{ng} / \mathrm{ml} ; \mathrm{P}<0.001)$. Treatment with CNX-010-49 significantly lowered plasma insulin levels by $\sim 40 \%(0.89 \pm 0.11$ vs $1.94 \pm 0.29 \mathrm{ng} / \mathrm{ml} ; \mathrm{P}<$ $0.05)$ when compared with the hyperinsulinemic HFD animals (Figure 6A). A similar trend was observed with fed insulin. Along with reduced insulin levels, insulin sensitivity was significantly improved in CNX-010-49 treated animals as evident from improved insulin tolerance test, reduced skeletal muscle phospho-JNK and reduced subcutaneous adipose phospho-eIF $2 \alpha$ levels
(Figure 6C, D \& E). Also we observed a significant decrease in mRNA expressions of PDK4 and TRIM63 in muscle tissue of CNX-010-49 treated animals indicating a possible improvement in glucose oxidation (Figure 6F \& G).

\section{CNX-010-49 improves lipid profile in DIO mice}

The effect of treatment on circulating TG levels is represented in Figure 7A.

In HFD control animals, the TG was increased by $\sim 1.7$ fold $(210 \pm 8 \mathrm{mg} / \mathrm{dl} ; \mathrm{P}<0.001)$ when compared to lean control $(128 \pm 8 \mathrm{mg} / \mathrm{dl})$ during the study period. On the other hand, the HFD fed animals treated with CNX-01049 showed $\sim 20 \%$ reduction in TG levels $(165 \pm 9 \mathrm{mg} / \mathrm{dl}$; $\mathrm{P}<0.001$ ) when compared to HFD control. The decrease in plasma TG upon CNX-010-49 treatment was observed from week 1 and was maintained throughout the study period. Also CNX-010-49 treatment has shown a non-significant reduction in the liver TG levels as compared to HFD control (Figure 7B).

We analyzed expression of fatty acid transporter CD36 and PPAR $\alpha$ which is involved in fat oxidation in liver tissue. As expected expression of CD36 increased by $\sim 1.5$ fold and a significant decrease in PPAR $\alpha$ in HFD animals as compared to lean control indicating increased fat 


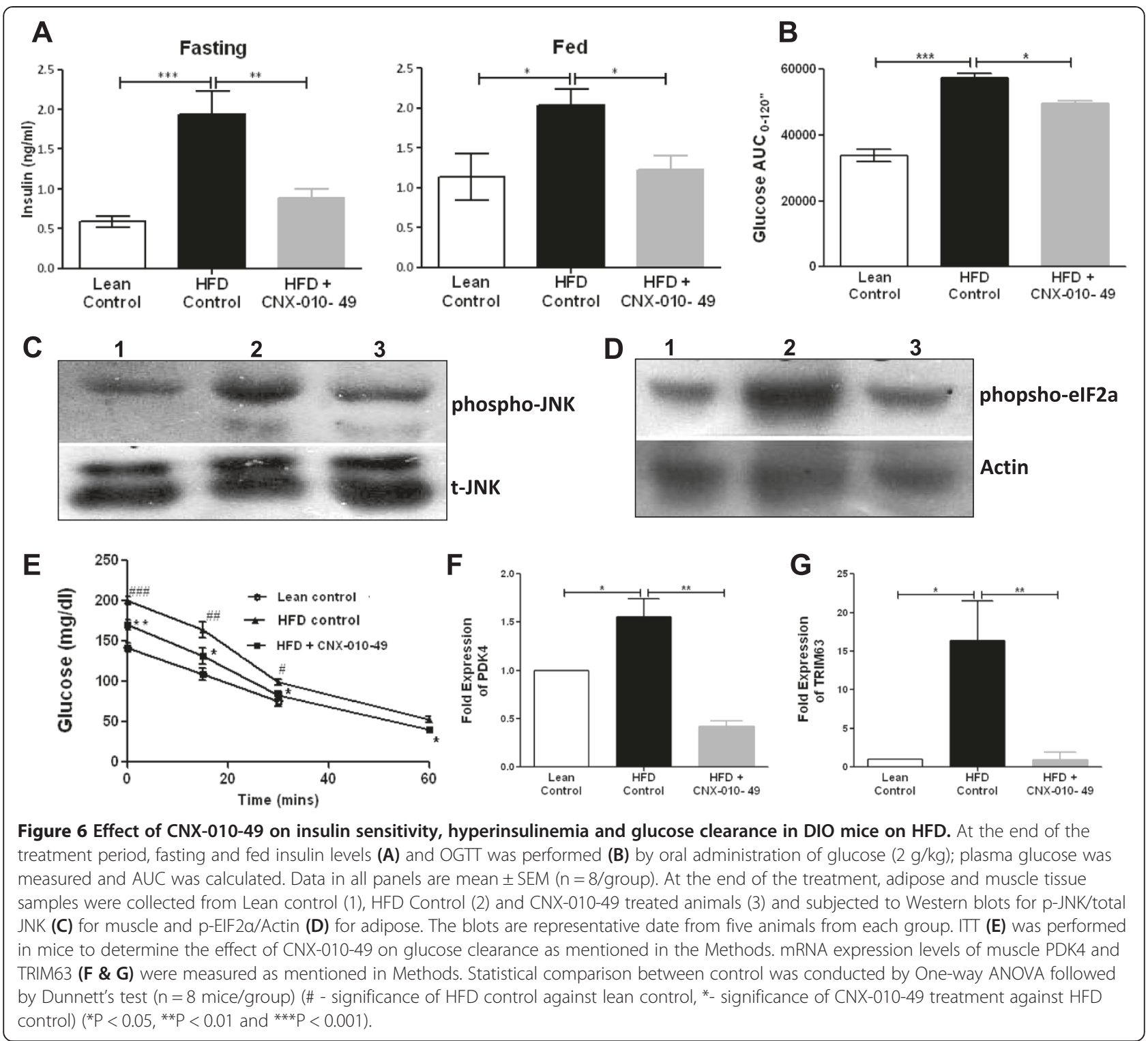

uptake and decreased fatty acid oxidation. Treatment with CNX-010-49 showed a decrease in CD36 and increased PPAR $\alpha$ expression indicating a decreased fat uptake and improved fat oxidation in liver as evident from decreased liver and serum TG levels (Figure 7C \& D).

\section{CNX-010-49 has a potential to improve thermogenesis and reduce body weight}

In the lean control animals, a gradual increase in body weight was observed during the 10 weeks study period ( $25.6 \mathrm{~g}$ to $28.1 \mathrm{~g}$ ). In contrast, body weight of HFD control animals showed a rapid increase and recorded $\sim 18 \%$ increase by end of the study ( $34.7 \mathrm{~g}$ to $41 \mathrm{~g}$ ). Treatment with CNX-010-49 prevented the weight gain by $\sim 20 \%$ (Figure 8A) without any change in the feed consumption (data not shown). We did not observe any significant increase in body weight from week 1 rather CNX-010-49 treatment decreased the body weight gradually till week 5 and later maintained the same during complete treatment period.

Histological analysis of white adipose tissue revealed an increase in adipocytes size in HFD animals compared to that of lean control. Treatment with CNX-010-49 reduced adipocytes size significantly by $\sim 30 \%$ (Figure $8 \mathrm{C}$ \& D). Compared to HFD control animals, CNX-01049 treatment enhanced non-shivering thermogenesis (Figure 8B). We observed a significant decrease in markers of brown fat phenotype and thermogenesis; positive regulatory domain containing 16 (PRDM16) and uncoupling protein 1 (UCP1) in HFD control adipocytes. CNX-010-49 

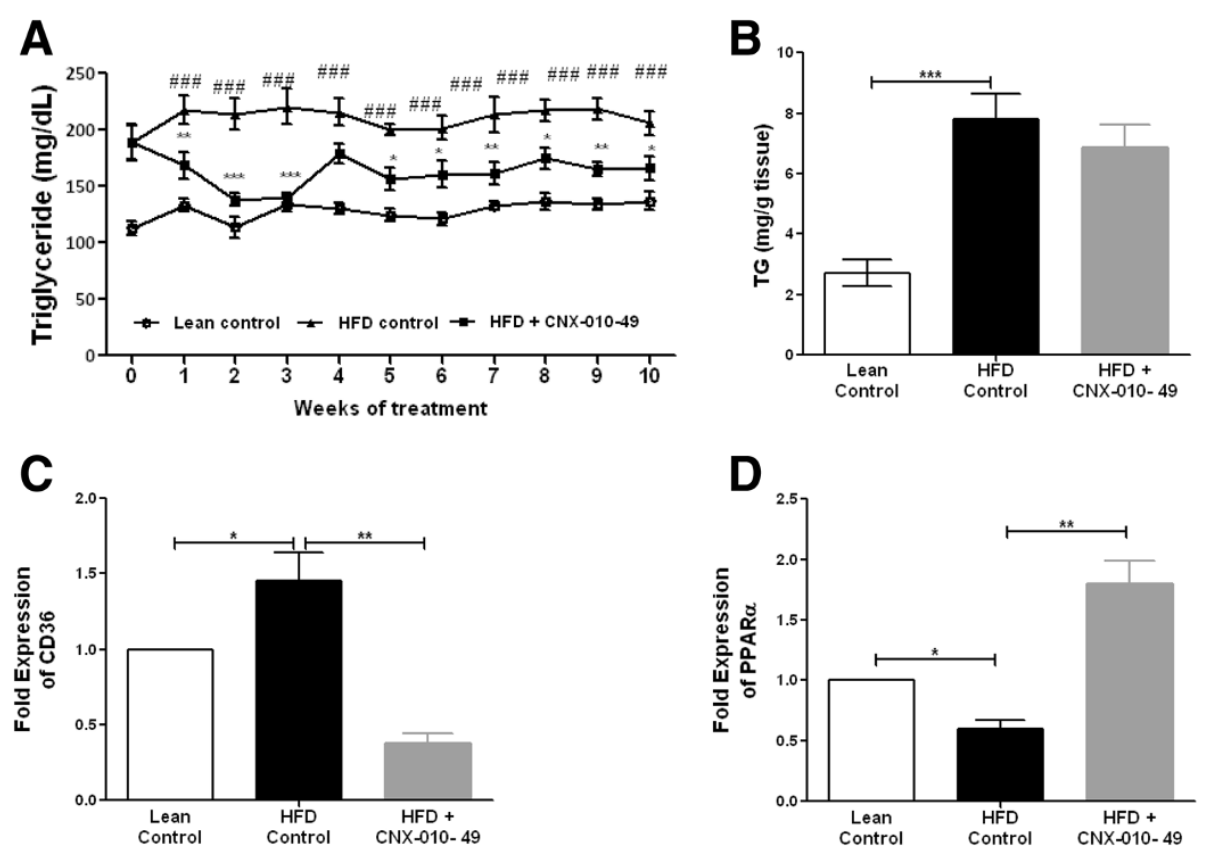

Figure 7 Effect of CNX-010-49 on lipid profile in DIO mice. Fasting serum TG levels (A) were monitored weekly. After the study termination, liver TG (B) was analyzed. Data in all panels are mean \pm SEM $(n=8$ mice/group). mRNA expression levels of liver CD36 and PPARa (C \& D) were measured as mentioned in Methods. Statistical comparison was conducted by One-way ANOVA followed by Dunnett's test or repeated measures ANOVA followed by Bonferroni correction (A) ( $n=8$ mice/group). Two-way repeated measures ANOVA indicated that CNX-010-49 significantly reduced the Fasting serum TG $(p=0.001 ; F=1.865 ; D f=20)$. (\# - significance of HFD control against lean control, *- significance of CNX-010-49 treatment against HFD control) $\left({ }^{*} \mathrm{P}<0.05\right.$, ${ }^{* *} \mathrm{P}<0.01$ and $\left.{ }^{* * *} \mathrm{P}<0.001\right)$.

treatment restored both PRDM16 and UCP1 protein expression thus shown a potential to enhance brown fat phenotype and thermogenesis (Figure 8C).

Serum leptin levels were elevated in HFD control animals compared to lean control (43 ng/ml vs $1.24 \mathrm{ng} / \mathrm{ml}$ ). Treatment with CNX-010-49 reduced serum leptin levels significantly by $\sim 50 \%(22 \mathrm{ng} / \mathrm{ml}$ vs $43 \mathrm{ng} / \mathrm{ml}$ ) (Figure $8 \mathrm{E}$ ) in comparison with the HFD control animals.

\section{CNX-010-49 has a potential reduce markers associated with cardio vascular risks}

Serum IL6 and PAI-1 levels (markers that are involved in stress and cardio protection) in HFD control animals were elevated significantly by 3 fold $(161 \mathrm{pg} / \mathrm{ml}$ vs $50 \mathrm{pg} / \mathrm{ml})$ and 3.5 fold $(375 \mathrm{ng} / \mathrm{ml}$ vs $94 \mathrm{ng} / \mathrm{ml})$ respectively compared to lean controls. Also we observed a nonsignificant decrease $(\sim 30 \%)$ in serum Fetuin-A levels in HFD control animals compared to lean controls. Treatment with CNX-010-49 decreased serum IL6 and PAI-1 levels significantly by $\sim 75 \%(34 \mathrm{pg} / \mathrm{ml}$ vs $161 \mathrm{pg} / \mathrm{ml})$ and $\sim 60 \%(148 \mathrm{ng} / \mathrm{ml}$ vs $375 \mathrm{ng} / \mathrm{ml})$ in comparison with HFD control animals. CNX-010-49 treatment increased serum Fetuin levels as compared to HFD control (3.2 ng/ml vs $1.2 \mathrm{ng} / \mathrm{ml}$ ) (Figure 9A-C).

\section{Discussion}

It is evident from multiple studies that glucocorticoids excess plays an important role in the development of metabolic syndrome, in particular T2DM [13]. Also it is confirmed from many recent studies that tissue specific glucocorticoids are involved in obesity and insulin resistance against the circulatory glucocorticoids [35-37].

The effect seen in these studies is an evidence to strengthen the understanding that tissue specific glucocorticoids play a major role in controlling metabolic syndrome. The pathology observed was not restricted to a particular tissue rather from multiple tissues. The therapeutic potential will be appreciated when we restrict/reduce the tissue level cortisol, an active glucocorticoid in multiple tissues.

In the present study, we have used a highly potent and selective 11 $\beta$-HSD1 inhibitor CNX-010-49 to study the multiple aspects of the metabolic dysregulations as seen in the metabolic syndrome in DIO mice on HFD. CNX010-49 is an orally dosable small molecule inhibitor of $11 \beta$-HSD1 which has a half-life of $7 \mathrm{~h}$. It has shown a good tissue distribution and 11 $\beta$-HSD1inhbition in multiple tissues like liver, skeletal muscle and adipose tissue. We did not observe brain 11ß-HSD1 inhibition with CNX-010-49 indicating there is no safety concerns in 
A

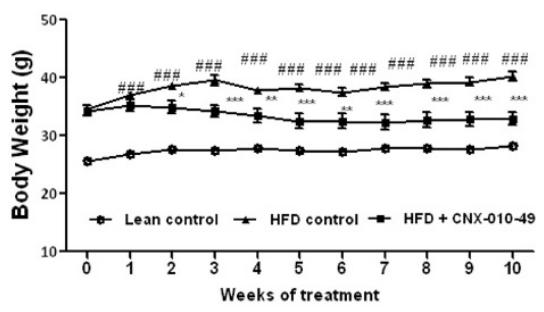

C

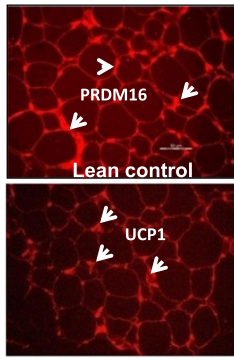

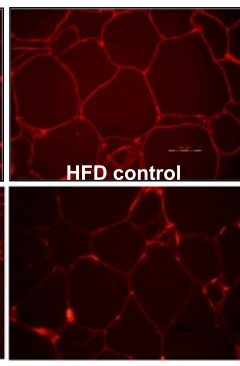

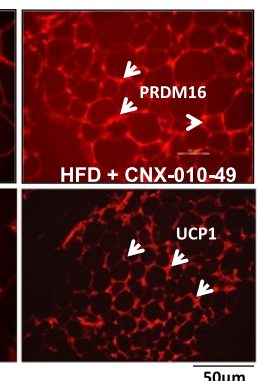

\section{B}

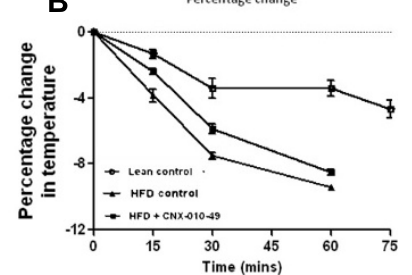

D

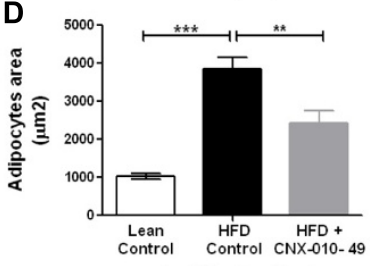

E

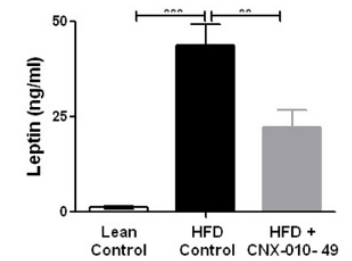

Figure 8 Effect of CNX-010-49 on thermogenesis and body weight in DIO mice. Body weight was measured weekly (A). Non-shivering thermogenesis was measured as described in the methods (B). Immunohistochemistry of PRDM16 and UCP1 (C) in subcutaneous adipose tissue sections was performed as mentioned in the Methods. Subcutaneous adipocytes size (D) and serum leptin (E) levels were measured at the end of treatment. Statistical comparison was conducted by One-way ANOVA followed by Dunnett's test or repeated measures ANOVA followed by Bonferroni correction (A) ( $n=8$ mice/group). Two-way repeated measures ANOVA indicated that CNX-010-49 significantly reduced body weight $(p=0.001 ; F=14.02 ; D f=22)$. (\# - significance of HFD control against lean control, * significance of CNX-010-49 treatment against HFD control) $\left({ }^{*} \mathrm{P}<0.05,{ }^{* *} \mathrm{P}<0.01\right.$ and $\left.{ }^{* * *} \mathrm{P}<0.001\right)$.

terms of hypothalamic-pituitary-adrenal axis (HPA axis) activation [38]. Since several previous studies from both T2DM humans and rodents have demonstrated elevated tissue specific glucocorticoids [13,18-20], we did not measure the tissue cortisol levels in our study.

Gluconeogenesis is one of the basic features of hepatocytes. Abnormal gluconeogenesis will lead to both fasting and non-fasting glucose release in patients with type 2 diabetes. It is well established that $11 \beta$-HSD1 controls key gluconeogenic genes PEPCK and G6PC expression $[39,40]$. Our data clearly demonstrate that inhibition of hepatic 11ß-HSD1 by CNX-010-49 suppress hepatic glucose output significantly along with reduced expression of PEPCK and G6PC in cultured mouse hepatocytes. DIO mice have shown a significant increase in fasting glucose which was inhibited by treatment with CNX010-49. When challenged with pyruvate, CNX-010-49 treated animals had shown a reduction in glucose levels indicating reduced gluconeogenic state of liver. These data from both in vitro and in vivo clearly demonstrate the role of $11 \beta$-HSD1 in hyperglycemia and inhibition can give a potential benefit in controlling both fasting and non-fasting hyperglycemia.

Glucocorticoid excess is known to induce insulin resistance in skeletal muscle. This has a significant effect on the glucose clearance in the periphery. It has been shown that activity and expression of $11 \beta-H S D 1$ in skeletal muscle has a significant impact on muscle insulin resistance [23]. Also recent studies have shown that insulin resistance can accelerate muscle protein degradation by activating ubiquitin-proteasome system [41]. Glucocorticoids are known to increase PDK4 $[42,43]$ and TRIM63 (an E3 ubiquitin protein ligase also known as MuRF1) in skeletal muscle cells [44]. Treatment with CNX-010-49 reduced hyperinsulinemia (both fasting and fed plasma insulin levels) and improved peripheral insulin sensitivity as evident from improved insulin tolerance test which was further supported by reduced glucose intolerance. This improvement in insulin sensitivity was further supported by reduced phospho-JNK and phospho-eIF2 $\alpha$ levels in skeletal muscle and adipose tissues of treated animals respectively. Treatment with CNX-010-49 reduced both PDK4 and TRIM63 expression along with restoration of mitochondrial copy number both in vitro and in vivo. In adipose tissue, treatment with CNX-010-49 inhibited lipolysis. Collectively these data suggests an overall improvement in the insulin sensitivity in the periphery.

Elevated tissue specific glucocorticoids are known to cause dyslipidemia and insulin resistance. They increase circulating triglyceride levels, hepatic de novo TAG synthesis and storage [45,46]. Elevated CD36 expression is known to increase hepatic triglyceride storage and 

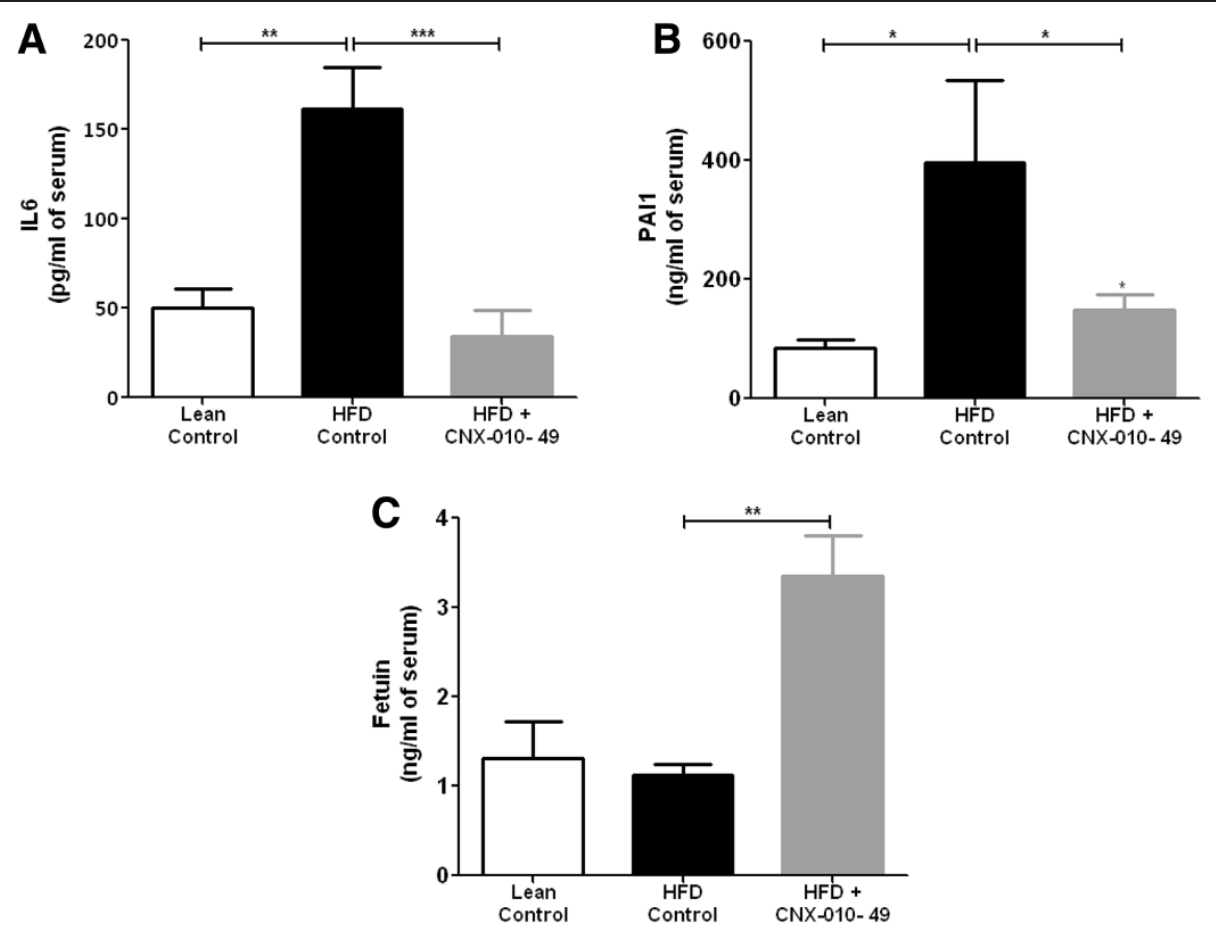

Figure 9 Effect of CNX-010-49 on markers associated with cardio vascular risks. At the end of the treatment, (A), PAl1 (B) and FetuinA (C) levels in the serum were measured by ELISA. All the values are expressed as Mean \pm SEM. Statistical comparison was conducted by One-way ANOVA followed by Dunnett's test ( $n=8$ mice/group) $\left(* P<0.05\right.$, ${ }^{* *} P<0.01$ and ${ }^{* * *} P<0.001$ ).

secretion [47]. Serum TG levels were very high in the HFD control mice. Treatment with CNX-010-49 reduced serum TG significantly indicating the role of $11 \beta$ HSD1 in dyslipidemia. A non-significant reduction in hepatic triglyceride content was observed with CNX010-49 treatment along with decreased CD36 expression indicating that reduced serum TG is not because of accumulation in liver. We also observed a significant increase in PPAR $\alpha$ expression in liver indicating treatment might have increased fatty acid oxidation. It is reported in the literature that activation of PPAR $\alpha$ reduces $11 \beta$ HSD1 expression and activity in liver [48].

The role of $11 \beta-H S D 1$ in obesity is well established both by pharmacological interventions and also by knockout studies $[28,30,32,49,50]$. In agreement with the previous reports, we observed a significant decrease in body weight with CNX-010-49 treatment without altering the feed consumption rate (data not shown). CNX-010-49 treatment has reduced both adipocyte size and serum leptin levels significantly. Glucocorticoids are known to decrease non-shivering thermogenesis and favors lipid storage in adipose tissue along with significant decrease in UCP1 expression [51]. Recently it has been shown that PRDM16 induces brown fat phenotype in white adipose tissue [52]. Also it induces many other genes including UCP1 which are directly involved in uncoupled cellular respiration and energy expenditure [53]. Treatment with
CNX-010-49 restores the expression of both PRDM16 and UCP1 in white adipose tissue. The relation between glucocorticoids and PRDM16 is still needs to be established.

Vascular calcification is known to be associated with cardiovascular disease. Recently it has been shown that serum Fetuin-A inhibits calcification [54,55]. Dexamethasone has been shown to suppress the expression of genes that inhibit calcification [56]. Elevated plasma levels of PAI-1 are known to associate with atherothrombosis and insulin resistance [57]. Glucocorticoids are known to increase the production of PAI-1 from adipose tissue [58]. Systemic chronic inflammation is a risk factor for cardiovascular disease where IL-6 act as central regulator [59]. CNX-010-49 treatment increased the serum Fetuin-A levels and decreased PAI-1 and IL-6 levels significantly indicating a potential cardiovascular benefit.

\section{Conclusions}

In summary, CNX-010-49 is a selective and 'pan' tissue acting, orally bioavailable 11ß-HSD1 inhibitor. Pharmacological inhibition of 11ß-HSD1 with CNX-010-49 has normalized most of metabolic dysregulations like hyperglycemia, insulin resistance and dyslipidemia along with body weight. 
CNX-010-49 is one of our lead compound in our discovery program. Further characterization is necessary before progressing to human studies.

\section{Additional file}

Additional file 1: Arrive guidelines followed in the current study.

\begin{abstract}
Abbreviations

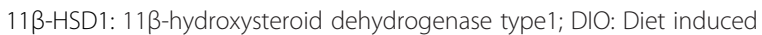
obesity; OGTT: Oral Glucose Tolerance Test; PAI-1: Plasminogen activator inhibitor-1; GCs: Glucocorticoids; UCP: Uncoupling protein; T2DM: Type 2 Diabetes Mellitus; TNFa: Tumor necrosis factor alpha; ALT: Aminotransferase; LDL: Low-density lipoprotein; IRS1: Insulin receptor substrate 1; IBMX: Isobutylmethylxanthine; HFD: High fat diet; ITT: Insulin tolerance test; PTT: Pyruvate tolerance test; G6PC: Glucose-6-phosphatase; PEPCK: Phosphoenolpyruvate carboxykinase 1; PDK4: Pyruvate dehydrogenase kinase 4; TRIM63: Tripartite motif containing 63; TG: Triglyceride; PRDM16: Positive regulatory domain containing 16; HPA axis: Hypothalamic-pituitary-adrenal axis.
\end{abstract}

\section{Competing interests}

All the authors are employees of Connexios Life Sciences Pvt Ltd and declare that they have no competing interests.

\section{Authors' contributions}

$\mathrm{KH}, J \mathrm{~S}, \mathrm{NS}, \mathrm{VSK}, \mathrm{MNL}, \mathrm{VS}, \mathrm{CH}, \mathrm{GVB}, \mathrm{BSN}, \mathrm{ASG}$, SP carried out experiments; TMA, AD, MKS, AMO, YM, MW, SBP and JMR planned/executed the study and analyzed data. SBP wrote the manuscript. All authors read and approved the final manuscript.

\section{Acknowledgements}

We thank Dr. M K Verma and Aseem Premnath, Connexios Life Sciences for the review of the article. These studies were supported by Connexios Life Sciences PVT LTD, a Nadathur Holdings Company.

Received: 7 February 2014 Accepted: 29 July 2014

Published: 7 August 2014

\section{References}

1. Hadoke PWF, lqbal J, Walker BR: Therapeutic manipulation of glucocorticoid metabolism in cardiovascular disease. Br J Pharmacol 2009, 156(5):689-712.

2. Friedman TC, Mastorakos G, Newman TD, Mullen NM, Horton EG, Costello R, Papadopoulos NM, Chrousos GP: Carbohydrate and lipid metabolism in endogenous hypercortisolism: shared features with metabolic syndrome $X$ and NIDDM. Endocr J 1996, 43(6):645-655.

3. Stewart PM, Krozowski ZS: 11 beta-Hydroxysteroid dehydrogenase. Vitam Horm 1999, 57:249-324.

4. Ricketts ML, Verhaeg JM, Bujalska I, Howie AJ, Rainey WE, Stewart PM: Immunohistochemical localization of type 111 beta-hydroxysteroid dehydrogenase in human tissues. J Clin Endocrinol Metab 1998, 83:1325-1335.

5. Whorwood CB, Mason Jl, Ricketts ML, Howie AJ, Stewart PM: Detection of human 11 beta-hydroxysteroid dehydrogenase isoforms using reverse-transcriptase-polymerase chain reaction and localization of the type 2 isoform to renal collecting ducts. Mol Cell Endocrinol 1995, 110(1-2):R7-R12

6. Dzyakanchuk AA, Balázs Z, Nashev LG, Amrein KE, Odermatt A: 11 betaHydroxysteroid dehydrogenase 1 reductase activity is dependent on a high ratio of $\mathrm{NADPH} / \mathrm{NADP}(+)$ and is stimulated by extracellular glucose. Mol Cell Endocrinol 2009, 301(1-2):137-141.

7. Hughes KA, Manolopoulos KN, lqbal J, Cruden NL, Stimson RH, Reynolds RM, Newby DE, Andrew R, Karpe F, Walker BR: Recycling between cortisol and cortisone in human splanchnic, subcutaneous adipose, and skeletal muscle tissues in vivo. Diabetes 2012, 61(6):1357-1364.

8. Shpilberg Y, Beaudry JL, D'Souza A, Campbell JE, Peckett A, Riddell MC: A rodent model of rapid-onset diabetes induced by glucocorticoids and high-fat feeding. Dis Model Mech 2012, 5(5):671-680.
9. Cusin I, Rouru J, Rohner-Jeanrenaud F: Intracerebroventricular glucocorticoid infusion in normal rats: induction of parasympathetic-mediated obesity and insulin resistance. Obes Res 2001, 9(7):401-406.

10. Zakrzewska KE, Cusin I, Stricker-Krongrad A, Boss O, Ricquier D, Jeanrenaud $B$, Rohner-Jeanrenaud F: Induction of obesity and hyperleptinemia by central glucocorticoid infusion in the rat. Diabetes 1999, 48(2):365-370.

11. Moriscot A, Rabelo R, Bianco AC: Corticosterone inhibits uncoupling protein gene expression in brown adipose tissue. Am J Physiol 1993 265(1 Pt 1):E81-E87.

12. Strack AM, Bradbury MJ, Dallman MF: Corticosterone decreases nonshivering thermogenesis and increases lipid storage in brown adipose tissue. Am J Physiol 1995, 268(1 Pt 2):R183-R191.

13. Rask E, Olsson T, Söderberg S, Andrew R, Livingstone DE, Johnson O, Walker BR: Tissue-specific dysregulation of cortisol metabolism in human obesity. J Clin Endocrinol Metab 2001, 86(3):1418-1421.

14. Kotelevtsev $Y$, Holmes MC, Burchell A, Houston PM, Schmoll D, Jamieson P, Best R, Brown R, Edwards CRW, Seckl JR, Mullins JJ: 11 \{beta\}-

Hydroxysteroid dehydrogenase type 1 knockout mice show attenuated glucocorticoid-inducible responses and resist hyperglycemia on obesity or stress. PNAS 1997, 94(26):14924-14929.

15. Masuzaki H, Paterson J, Shinyama H, Morton NM, Mullins JJ, Seckl JR, Flier JS: A transgenic model of visceral obesity and the metabolic syndrome. Science 2001, 294(5549):2166-2170.

16. Masuzaki H, Yamamoto $H$, Kenyon CJ, Elmquist JK, Morton NM, Paterson JM, Shinyama H, Sharp MG, Fleming S, Mullins JJ, Seckl JR, Flier JS: Transgenic amplification of glucocorticoid action in adipose tissue causes high blood pressure in mice. J Clin Invest 2003, 112(1):83-90.

17. Rask E, Walker BR, Söderberg S, Livingstone DE, Eliasson M, Johnson O, Andrew R, Olsson T, Clin J: Tissue-specific changes in peripheral cortisol metabolism in obese women: increased adipose 11ß-hydroxysteroid dehydrogenase type 1 activity. J Clin Endocrinol Metab 2002, 87(7):3330-3336.

18. Paulmyer-Lacroix O, Bouliu S, Oliver C, Alessi M-C, Grino M: Expression of the mRNA coding for $11 \beta$-hydroxysteroid dehydrogenase type 1 in adipose tissue from obese patients: an in situ hybridization study. J Clin Endocrinol Metab 2002, 87(6):2701-2705.

19. Livingstone DE1, Jones GC, Smith K, Jamieson PM, Andrew R, Kenyon CJ, Walker BR: Understanding the role of glucocorticoids in obesity: tissue-specific alterations of corticosterone metabolism in obese Zucker rats. Endocrinology 2000, 141(2):560-563.

20. Livingstone DE, Kenyon CJ, Walker BR: Mechanisms of dysregulation of 11 beta-hydroxysteroid dehydrogenase type 1 in obese Zucker rats. J Endocrinol 2000, 167:533-539.

21. Harno E, Cottrell EC, Keevil BG, DeSchoolmeester J, Bohlooly-Y M, Andersén $H$, Turnbull AV, Leighton B, White A: 11-Dehydrocorticosterone causes metabolic syndrome, which is prevented when 11ß-HSD1 is knocked out in livers of male mice. Endocrinology 2013, 154(10):3599-3609.

22. Lavery GG, Zielinska AE, Gathercole LL, Hughes B, Semjonous N, Guest $P$, Saqib K, Sherlock M, Reynolds G, Morgan SA, Tomlinson JW, Walker EA, Rabbitt EH, Stewart PM: Lack of significant metabolic abnormalities in mice with liver-specific disruption of $11 \beta$-hydroxysteroid dehydrogenase type 1. Endocrinology 2012, 153(7):3236-3248.

23. Morgan SA, Sherlock M, Gathercole LL, Lavery GG, Lenaghan C, Bujalska IJ, Laber D, Yu A, Convey G, Mayers R, Hegyi K, Sethi JK, Stewart PM, Smith DM, Tomlinson JW: 11 beta-hydroxysteroid dehydrogenase type 1 regulates glucocorticoid-induced insulin resistance in skeletal muscle. Diabetes 2009, 58(11):2506-2515.

24. Alberts P, Nilsson C, Selen G, Engblom LO, Edling NH, Norling S, Klingstrom G, Larsson C, Forsgren M, Ashkzari M, Nilsson CE, Fiedler M, Bergqvist E, Ohman B, Bjorkstrand E, Abrahmsen LB: Selective inhibition of 11 betahydroxysteroid dehydrogenase type 1 improves hepatic insulin sensitivity in hyperglycemic mice strains. Endocrinology 2003, 144(11):4755-4762.

25. Alberts $P$, Engblom L, Edling N, Forsgren M, Klingstrom G, Larsson C, Ronquist-Nii Y, Ohman B, Abrahmsen L: Selective inhibition of 11 beta-hydroxysteroid dehydrogenase type 1 decreases blood glucose concentrations in hyperglycaemic mice. Diabetologia 2002, 45(11):1528-1532.

26. Barf T, Vallgarda J, Emond R, Haggstrom C, Kurz G, Nygren A, Larwood V, Mosialou E, Axelsson K, Olsson R, Engblom L, Edling N, Ronquist-Nii Y, Ohman B, Alberts $P$, Abrahmsen L: Arylsulfonamidothiazoles as a new class of potential antidiabetic drugs: discovery of potent and selective inhibitors of the 11 beta-hydroxysteroid dehydrogenase type 1 . J Med Chem 2002, 45(18):3813-3815. 
27. Bhat BG, Hosea N, Fanjul A, Herrera J, Chapman J, Thalacker F, Stewart PM, Rejto PA: Demonstration of proof of mechanism and pharmacokinetics and pharmacodynamic relationship with 4'-cyano-biphenyl-4-sulfonic acid (6-amino-pyridin-2-yl)-amide (PF-915275), an inhibitor of 11 -hydroxysteroid dehydrogenase type 1, in cynomolgus monkeys. J Pharmacol Exp Ther 2008, 324(1):299-305.

28. Hermanowski-Vosatka A, Balkovec JM, Cheng K, Chen HY, Hernandez M, Koo GC, Le Grand CB, Li Z, Metzger JM, Mundt SS, Noonan H, Nunes CN, Olson SH, Pikounis B, Ren N, Robertson N, Schaeffer JM, Shah K, Springer MS, Strack AM, Strowski M, Wu K, Wu T, Xiao J, Zhang BB, Wright SD, Thieringer R: 11 beta-HSD1 inhibition ameliorates metabolic syndrome and prevents progression of atherosclerosis in mice. J Exp Med 2005, 202(4):517-527.

29. Sundbom M, Kaiser C, Björkstrand E, Castro VM, Larsson C, Selén G, Nyhem CS, James SR: Inhibition of 11 betaHSD1 with the S-phenylethylaminothiazolone BVT116429 increases adiponectin concentrations and improves glucose homeostasis in diabetic KKAy mice. BMC Pharmaco 2008, 10.1186/1471 2210-8-3.

30. Taylor A, Irwin N, McKillop AM, Flatt PR, Gault VA: Sub-chronic administration of the 11 beta-HSD1 inhibitor, carbenoxolone, improves glucose tolerance and insulin sensitivity in mice with diet-induced obesity. Biol Chem 2008 389(4):441-445.

31. Rosenstock J, Banarer S, Fonseca VA, Inzucchi SE, Sun W, Yao W, Hollis G Flores R, Levy R, Williams WV, Seckl JR, Huber R: The 11-beta-hydroxysteroid dehydrogenase type 1 inhibitor INCB13739 improves hyperglycemia in patients with type 2 diabetes inadequately controlled by metformin monotherapy. Diabetes Care 2010, 33(7):1516-1522.

32. Feig PU, Shah S, Hermanowski-Vosatka A, Plotkin D, Springer MS, Donahue S, Thach C, Klein EJ, Lai E, Kaufman KD: Effects of an 11ß-hydroxysteroid dehydrogenase type 1 inhibitor, MK-0916, in patients with type 2 diabetes mellitus and metabolic syndrome. Diabetes Obes Metab 2011, 13(6):498-504

33. Seglenin PO: Preparation of isolated rat liver cells. Methods Cell Biol 1976, $13: 29-83$

34. Kilkenny C, Browne WJ, Cuthill IC, Emerson M, Altman DG: Improving bioscience research reporting: the ARRIVE guidelines for reporting animal research. PLOS Biol 2010, 8(6):e1000412

35. Ohshima K, Shargill NS, Chan TM, Bray GA: Adrenalectomy reverses insulin resistance in muscle from obese (ob/ob) mice. Am J Physiol 1984, 246:E193-E197.

36. Okada S, York DA, Bray GA: Mifepristone (RU 486), a blocker type II glucocorticoid and progestin receptors, reverses a dietary form obesity. Am J Physiol 1992, 262:R1106-R1110.

37. Shimomura Y, Bray GA, Lee M: Adrenalectomy and steroid treatment in obese (ob/ob) and diabetic (db/db) mice. Horm Metab Res 1987 19:295-299.

38. Chrousos GP: Is 11 beta-hydroxysteroid dehydrogenase type 1 a good therapeutic target for blockade of glucocorticoid actions? Proc Natl Acad Sci U S A 2004, 101(17):6329-6330.

39. Fan Z, Du H, Zhang M, Meng Z, Chen L, Liu Y: Direct regulation of glucose and not insulin on hepatic hexose-6-phosphate dehydrogenase and 11ß-hydroxysteroid dehydrogenase type 1. Mol Cell Endocrinol 2011, 333(1):62-69.

40. Ma R, Zhang W, Tang K, Zhang H, Zhang Y, Li D, Li Y, Xu P, Luo S, Cai W, Ji T, Katirai F, Ye D, Huang B: Switch of glycolysis to gluconeogenesis by dexamethasone for treatment of hepatocarcinoma. Nat Commun 2013, 4:2508.

41. Wang $\mathrm{X}, \mathrm{Hu} Z, \mathrm{Hu} J$, Du J, Mitch WE: Insulin resistance accelerates muscle protein degradation: Activation of the ubiquitin-proteasome pathway by defects in muscle cell signaling. Endocrinology 2006, 147(9):4160-4168.

42. Salehzadeh F, Al-Khalili L, Kulkarni SS, Wang M, Lönnqvist F, Krook A: Glucocorticoid-mediated effects on metabolism are reversed by targeting 11 beta hydroxysteroid dehydrogenase type 1 in human skeletal muscle. Diabetes Metab Res Rev 2009, 25(3):250-258.

43. Connaughton S, Chowdhury F, Attia RR, Song S, Zhang Y, Elam MB, Cook GA, Park EA: Regulation of pyruvate dehydrogenase kinase isoform 4 (PDK4) gene expression by glucocorticoids and insulin. Mol Cell Endocrinol 2010, 315(1-2):159-167.
44. Biedasek K, Andres J, Mai K, Adams S, Spuler S, Fielitz J, Spranger J: Skeletal muscle 11 beta-HSD1 controls glucocorticoid-induced proteolysis and expression of E3 ubiquitin ligases atrogin-1 and MuRF-1. PLoS One 2011 6(1):e16674.

45. Dolinsky W, Douglas DN, Lehner R, Vance DE: Regulation of the enzymes of hepatic microsomal triacylglycerol lipolysis and re-esterification by the glucocorticoid dexamethasone. Biochem J 2004, 378(Pt 3):967-974.

46. Mantha L, Palacios E, Deshaies Y: Modulation of triglyceride metabolism by glucocorticoids in diet-induced obesity. Am J Physiol 1999, 277(2 Pt 2):R455-R464

47. Koonen DP, Jacobs RL, Febbraio M, Young ME, Soltys $C L$, Ong $H$, Vance $D E$, Dyck JR: Increased hepatic CD36 expression contributes to dyslipidemia associated with diet-induced obesity. Diabetes 2007, 56(12):2863-2871.

48. Hermanowski-Vosatka A, Gerhold D, Mundt SS, Loving VA, Lu M, Chen Y, Elbrecht A, Wu M, Doebber T, Kelly L, Milot D, Guo Q, Wang PR, Ippolito M, Chao YS, Wright SD, Thieringer R: PPARalpha agonists reduce 11 betahydroxysteroid dehydrogenase type 1 in the liver. Biochem Biophys Res Commun 2000, 279(2):330-336.

49. Kotelevtsev $Y$, Holmes MC, Burchell A, Houston PM, Schmoll D, Jamieson P, Best R, Brown R, Edwards CR, Seckl JR, Mullins JJ: 11 beta-hydroxysteroid dehydrogenase type 1 knockout mice show attenuated glucocorticoidinducible responses and resist hyperglycemia on obesity or stress. Proc Natl Acad Sci U S A 1997, 94(26):14924-14929.

50. Morton NM, Paterson JM, Masuzaki H, Holmes MC, Staels B, Fievet C, Walker BR, Flier JS, Mullins JJ, Seckl JR: Novel adipose tissue-mediated resistance to diet-induced visceral obesity in 11 beta-hydroxysteroid dehydrogenase type 1-deficient mice. Diabetes 2004, 53(4):931-938.

51. Viengchareun S1, Penfornis P, Zennaro MC, Lombès M: Mineralocorticoid and glucocorticoid receptors inhibit UCP expression and function in brown adipocytes. Am J Physiol Endocrinol Metab 2001, 280(4):E640-E649.

52. Seale P, Kajimura S, Yang W, Chin S, Rohas LM, Uldry M, Tavernier G, Langin $D$, Spiegelman BM: Transcriptional control of brown fat determination by PRDM16. Cell Metab 2007, 6(1):38-54.

53. Ricquier D: Respiration uncoupling and metabolism in the control of energy expenditure. Proc Nutr Soc 2005, 64(1):47-52.

54. Maréchal C, Schlieper G, Nguyen P, Krüger T, Coche E, Robert A, Floege J, Goffin $E$, Jadoul M, Devuyst O: Serum fetuin-A levels are associated with vascular calcifications and predict cardiovascular events in renal transplant recipients. Clin J Am Soc Nephrol 2011, 6(5):974-985.

55. Westenfeld R, Schäfer C, Smeets R, Brandenburg VM, Floege J, Ketteler M, Jahnen-Dechent W: Fetuin-A (AHSG) prevents extraosseous calcification induced by uraemia and phosphate challenge in mice. Nephrol Dial Transplant 2007, 22(6):1537-1546.

56. Kirton JP, Wilkinson FL, Canfield AE, Alexander MY: Dexamethasone downregulates calcification-inhibitor molecules and accelerates osteogenic differentiation of vascular pericytes: implications for vascular calcification. Circ Res 2006, 98(10):1264-1272.

57. Alessi MC, Peiretti F, Morange P, Henry M, Nalbone G, Juhan-Vague I: Production of plasminogen activator inhibitor 1 by human adipose tissue: possible link between visceral fat accumulation and vascular disease. Diabetes 1997, 46(5):860-867.

58. Morange PE, Aubert J, Peiretti F, Lijnen HR, Vague P, Verdier M, Négrel R, Juhan-Vague I, Alessi MC: Glucocorticoids and insulin promote plasminogen activator inhibitor 1 production by human adipose tissue. Diabetes 1999, 48(4):890-895.

59. Willerson JT, Ridker PM: Inflammation as a cardiovascular risk factor. Circulation 2004, 109(21 Suppl 1):II2-II10.

doi:10.1186/2050-6511-15-43

Cite this article as: Anil et al:: A novel 11ß-hydroxysteroid dehydrogenase type1 inhibitor CNX-010-49 improves hyperglycemia, lipid profile and reduces body weight in diet induced obese C57B6/J mice with a potential to provide cardio protective benefits. BMC Pharmacology and Toxicology 2014 15:43. 